Revista Eletrônica Geografar, Curitiba, v. 2, Resumos do VI Seminário Interno de Pós-Graduação em Geografia, p. 61-61. Junho/2007

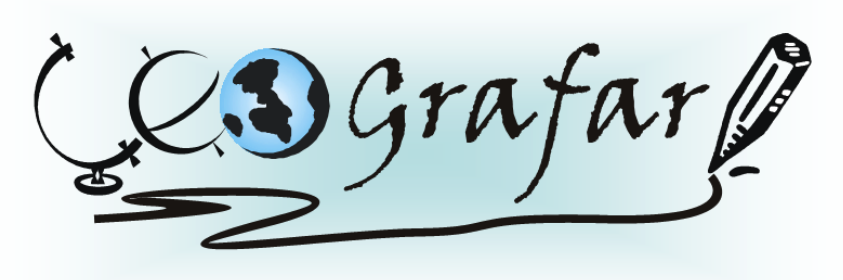

Revista Eletrônica do Programa de Pós-Graduação em Geografia - UFPR

\title{
PLANEJAMENTO MUNICIPAL E TURÍSTICO - INTEGRAÇÃO ESTRATÉGICA PARA O DESENVOLVIMENTO DOS MUNICÍPIOS COM POTENCIAL PARA O TURISMO
}

\author{
RENATA MARIA RIBEIRO ${ }^{1}$
}

A concepção da palavra planejamento infere a alguns, sensação de controle e engessamento da dinâmica natural do desenvolvimento. No entanto, a aproximação das linhas de estudos sobre planejamento nas organizações públicas ou da iniciativa privada, demonstra que à frente está quem prioriza ações prevendo etapas de planejamento, desenvolvimento, aplicação e análise de resultados. A necessidade de organização induz aos gestores ao reconhecimento quanto às técnicas de planejamento efícazes na resolução de problemas, no reordenamento territorial, e na busca do desenvolvimento municipal. A legislação referente à ordem municipal, o Estatuto das Cidades, a Lei de Responsabilidade Fiscal, os Planos Plurianuais, bem como as Leis de Diretrizes Orçamentárias, são formas de projetar orientações aos municípios sobre procedimentos cabíveis à ordem pública. Deste modo, metodologias específicas podem promover crescimento ordenado, sistemático e contínuo das organizações públicas, para benefício da população. $\mathrm{O}$ turismo, atividade produtiva do terceiro setor, depende do alinhamento municipal sob forma de planejamento. Esta técnica permite a este ambiente estruturado o desenvolvimento, e a movimentação da economia local através da geração de empregos diretos e indiretos, e ainda contribuir para a organização das infra-estruturas urbanas que beneficiam a população e turistas. Com base neste cenário, o estudo da metodologia do planejamento para o turismo, faz-se necessário prevendo que esta proposta possa ajustar as técnicas existentes aos moldes da legislação vigente no Brasil, e ainda, esclarecer sobre os passos necessários à condução ao desenvolvimento territorial e ordenado em municípios com potencial turístico. Deste modo, pretende-se demonstrar que, não basta estudar o planejamento do turismo. A legislação que rege as cidades é de fundamental importância, pois são partes integrantes no processo de desenvolvimento das cidades, mas que isoladamente, não passam de tentativas de organização do setor sem o respaldo das outras esferas legais pertinentes ao poder público.

Palavras-chave: planejamento, legislação, turismo.

1Doutoranda em Geografia - UFPR - email: renata.ribeiro@pucpr.br

Orientador: MARCOS AURÉLIO T. SILVEIRA 